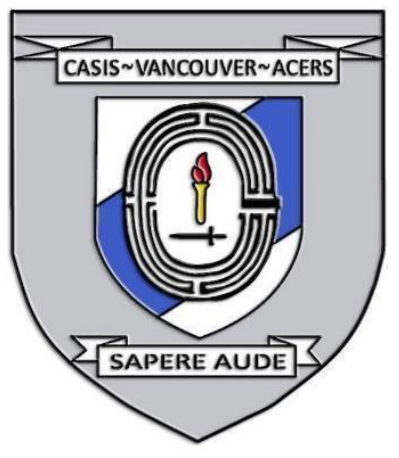

\title{
SOCIAL MEDIA AS A RECRUITMENT TOOL BY EXTREMIST GROUPS
}

Date: November $25^{\text {th }}, 2020$

Disclaimer: This briefing note contains the encapsulation of views presented by the speaker and does not exclusively represent the views of the Canadian Association for Security and Intelligence Studies.

\section{KEY EVENTS}

On November 25, 2020, Professor Mubin Shaikh presented Social Media as a Recruitment Tool by Extremist Groups at the 2020 CASIS West Coast Security Conference. The presentation was followed by a question and answer period with other speakers. The key points of discussion focused on how the rise of social media has created recruitment opportunities for extremist groups, and how these opportunities have compounded during the COVID-19 pandemic.

\section{NATURE OF DISCUSSION}

\section{Presentation}

Professor Mubin Shaikh discussed the emergence of social media as a recruitment tool for extremist groups, the difficulties introduced by COVID-19, and the implications for law enforcement.

\section{Question period}

The speaker examined alternative views and beliefs of radicalized individuals and how that may change their perception of success.

\section{BACKGROUND}

\section{Presentation}

Modern terrorism is full of complex groups of actors across a broad political spectrum conducting activities in a complex set of environments. This complexity holds true across all sorts of terrorism, whether it's Islamic Extremism or Right Wing Extremism. Those who commit acts of terror are now fully aware that it is not how many people you kill, it is how many people witness your acts of violence that will help carry your message. Social media and it's 
explosive growth over the past few decades have catalyzed this ability to spread hateful messages. Terrorist recruiting is no longer exclusive to dark alleys, but happens in broad daylight across all sorts of various social media platforms.

Social media is not only used for recruitment, but as a means of spreading the violent rhetoric terrorist groups espouse. While extremist groups are using these online platforms to spread their hateful messages, it is important that religious groups master the same messaging skills, in order to spread religious countermessages against the hate. In cases where the extremist groups are not claiming a religious background, counter messaging is just as important, but may have to come from more diverse sources.

The COVID-19 pandemic has catalyzed the move to online recruiting for extremist groups. While the move to online recruiting had begun well before COVID-19, as the pandemic pushes more people into virtual spaces, extremist groups are capitalizing on this new traffic. In the age of fake news and echo chambers, hateful messaging is spreading farther and faster than ever before as the world moves online. The end of COVID-19 is not in sight yet, and what the post-COVID-19 world will look like is still very unclear. The world should be prepared for new normals in our post-pandemic security environment.

\section{Question Period}

The interpretation of failure or success depends on each person's ideological or spiritual underpinning. What some may qualify as failure, others may qualify as success or delayed success. For example, some people believe that Jihad is the ultimate expression of faith and that being a martyr is the greatest occupation. If they die in battle, they do not consider that a failure because they believe they will go to heaven. For most people, it is difficult to contemplate the possibility of someone seeing death as part of a greater reward, and that is part of the reason we fail to understand radicalization in the first place.

\section{KEY POINTS OF DISCUSSION}

\section{Presentation}

- Extremist groups are increasingly looking towards social media for recruitment.

- Religious groups must continue to master counter-messaging by using the same social media tools which are being used to spread hate. 
- The COVID-19 pandemic has catalyzed a move to virtual spaces resulting in increased traffic online.

- The end of COVID-19 is not yet in sight, we must be prepared for all sorts of new normals in a post-pandemic world.

\section{Question period}

- The perception of failure or success is subject to ideological or spiritual underpinnings, so to understand radicalization, we need to understand a person's beliefs.

\section{(c) (1) ()}

EY No No This work is licensed under a Creative Commons Attribution-

NonCommercial-NoDerivatives 4.0 International License.

(C) (Mubin Shaikh, 2021)

Published by the Journal of Intelligence, Conflict, and Warfare and Simon Fraser University

Available from: https://jicw.org/ 